\title{
PENGARUH KESADARAN WAJIB PAJAK DAN SANKSI PAJAK TERHADAP KEPATUHAN WAJIB PAJAK KENDARAAN BERMOTOR DI KOTA KENDARI (Studi Pada Samsat Kota Kendari)
}

\author{
Oleh \\ Yuli Lestari Labangu ${ }^{1}$, Emillia Nurdin², Firmansyah Guntur ${ }^{3}$ \\ Jurusan Akuntansi Fakultas Ekonomi dan Bisnis Universitas Halu Oleo Kendari \\ Sulawesi Tenggara
}

\begin{abstract}
ABSTRAK
Penelitian ini bertujuan untuk menguji pengaruh kesadaran wajib pajak dan sanksi pajak terhadap kepatuhan wajib pajak kendaraan bermotor di Kota Kendari. Tujuan penelitian ini yaitu mengetahui pengaruh kesadaran wajib pajak dan sanksi pajak secara parsial terhadap kepatuhan wajib pajak kendaraan bermotor, dan mengetahui pengaruh kesadaran wajib pajak dan sanksi pajak secara simultan terhadap kepatuhan wajib pajak kendaraan bermotor. Populasi dalam Penelitian ini berjumlah 116.268 wajib pajak. Sampel pada penelitian ini berjumlah 100 wajib pajak. Metode pengumpulan data menggunakan kuesioner. Analisis data menggunakan metode analisis deskriptif dan analisis linear berganda. Penelitian ini juga menggunakan analisis faktor untuk memperlihatkan indikator yang paling berpengaruh dalam satu variabel. Hasil penelitian ini menunjukan bahwa (1) Kesadaran wajib pajak secara parsial berpengaruh terhadap kepatuhan wajib pajak kendaraan bermotor di Kota Kendari. (2) Sanksi pajak secara parsial berpengaruh terhadap kepatuhan wajib pajak kendaraan bermotor di Kota Kendari. (3) kesadaran wajib pajak dan sanksi pajak secara simultan terhadap kepatuhan wajib pajak kendaraan bermotor di Kota Kendari. Pada uji koefisien determinasinilai R Square sebesar 0,758, hal ini menunjukkan bahwa kemampuan variabel independen mampu menjelaskan variabel dependennya dengan nilai koefisien determinasi sebesar 75,8\%, sedangkan sisanya sebesar $24,2 \%$ dijelaskan oleh variabel lain yang tidak diteliti pada penelitian ini.
\end{abstract}

Kata Kunci : Kesadaran Wajib Pajak, Sanksi Pajak, Kepatuhan Wajib Pajak Kendaraan Bermotor.

\section{ABSTRACT}

This study aims to examine the effect of taxpayer awareness and tax sanctions on motor vehicle taxpayer compliance in Kendari City. The purpose of this study is to determine the effect of taxpayer awareness and tax sanctions partially on motor vehicle taxpayer compliance, and to know the effect of taxpayer awareness and tax sanctions simultaneously on motor vehicle taxpayer compliance. The population in this study amounted to 116,268 taxpayers. The sample in this study amounted to 100 taxpayers. The data collection method used a questionnaire. Data analysis using descriptive analysis method and multiple linear analysis. This study also uses factor analysis to show the most influential indicators in one variable. The results of this study indicate that (1) Taxpayer awareness partially affects the compliance of motor vehicle taxpayers in Kendari City. (2) Tax sanctions partially affect the compliance of motor vehicle taxpayers in Kendari City. (3) awareness of taxpayers and tax sanctions simultaneously on motor vehicle taxpayer compliance in Kendari City. In the determination coefficient test, the $R$ Square value is 0.758 , this indicates that the ability of the independent variable is able to explain the dependent variable with a determination coefficient value of $75.8 \%$, while the remaining $24.2 \%$ is explained by other variables not examined in this study.

Keywords: Taxpayer Awareness, Tax Sanctions, Motor Vehicle Taxpayer Compliance 


\section{PENDAHULUAN}

Di Indonesia banyaknya masalah kemiskinan, kesehatan, pendidikan, lingkungan dan transportasi serta prasarana umum lainnya, membutuhkan penanganan segera dari Pemerintah. Untuk menanggulangi masalah kemasyarakatan ini, penerimaan pajak sangat diharapkan sebagai sumber pembiayaan. Dengan demikian, seluruh warga negara memiliki peran penting dalam tugasnya membayar pajak, dalam menyelesaikan masalah sosial kemasyarakan serta lingkungan. Salah satu jenis pajak yang dipungut oleh pemerintah adalah pajak kendaraan bermotor atau PKB. Pajak kendaraan bermotor adalah pajak yang dipungut atas kepemilikan atau penguasaan kendaraan bermotor.

Kepatuhan wajib pajak Kendaraan Bermotor yaitu dimana Wajib Pajak memenuhi kewajiban perpajakannya dan melaksanakan hak perpajakan dengan baik dan benar sesuai dengan peraturan dan Undang-Undang pajak yang berlaku. Kepatuhan wajib pajak kendaraan bermotor dapat dipengaruhi oleh kesadaran wajib pajak dalam membayar pajak kendaraannya, jika seorang wajib pajak sadar akan membayar pajaknya, maka semakin meningkat tingkat kepatuhan wajib pajak dalam membayar pajak. Menurut Mutia (2014) kesadaran Wajib Pajak akan perpajakan adalah dimana rasa yang timbul dalam diri Wajib Pajak atas kewajibannya membayar pajak dengan ikhlas tanpa adanya unsur paksaan.

Kepatuhan wajib pajak kendaraan bermotor dapay di pengaruhi oleh sanksi pajak yang diberikan kepada wajib pajak yang melakukan pelanggaran pajak, semakin tinggi tingkat sanksi pajak yang diberikan kepada wajib pajak yang melanggar, maka semakin meningkat tingkat kepatuhan wajib pajak dalam membayar pajaknya. Menurut Mardiasmo (2018) sanksi perpajakan merupakan suatu jaminan atau pencegahan (preventif) bahwa ketentuan peraturan perundang- undangan perpajakan atau norma perpajakan akan dituruti/ ditaati/ dipatuhi.

Beberapa peneliti sebelumnya telah melakukan penelitian dan menyatakan bahwa kesadaran wajib pajak dan sanksi pajak memiliki pengaruh terhadap kepatuhan wajib pajak kendaraan bermotor, namun ada juga yang menyatakan bahwa sanksi pajak tidak berpengaruh. Adanya inkonsistensi hasil yang diperoleh dari beberapa peneliti sebelumnya menimbulkan adanya research gap. Penelitian yang dilakukan oleh Muslikhatul Ummah (2015), Dian Angriani dan Siti Khairani (2018), dan Anis Syamsu Rizal (2019) menyatakan bahwa sanksi pajak berpengaruh terhadap kepatuhan wajib pajak kendaraan bermotor. Namun, penelitian yang dilakukan oleh Agnes Shopia Irawati (2015) mengemukakan hal yang berbeda, bahwa sanksi pajak tidak berpengaruh terhadap kepatuhan wajib pajak kendaraan bermotor.

Saat ini di Kota Kendari, jumlah pemilik kendaraan bermotor terus bertambah, kebutuhan akan alat transportasi di zaman sekarang menjadi skala prioritas bagi masyarakat, karena memudahkan perjalanan ke tempat yang dituju dengan waktu cepat. Semakin meningkat jumlah kendaraan yang ada, maka semakin meningkat pula jumlah wajib pajak kendaraan bermotor tiap tahunnya. Hal ini akan sangat dirasakan oleh pemerintah daerah, karena dengan jumlah yang relatif meningkat terus, maka akan berimbas pada meningkatnya penerimaan pajak. Namun karena tidak sedikitnya penunggakan yang dilakukan oleh wajib pajak, maka belum maksimal penerimaan pajak yang diperoleh pemerintah. 
Tabel 1

Jumlah Wajib Pajak Kendaraan Bermotor dan Jumlah Wajib Pajak Yang Menunggak Di Kota Kendari

\begin{tabular}{|l|l|l|l|l|l|l|}
\hline Tahun & $\begin{array}{c}\text { Jumlah } \\
\text { Wajib } \\
\text { Pajak } \\
\text { Kendaraan } \\
\text { Bermotor }\end{array}$ & $\begin{array}{c}\text { Kendaraan } \\
\text { Roda Dua }\end{array}$ & $\begin{array}{c}\text { Kendaraan } \\
\text { Roda } \\
\text { Empat }\end{array}$ & $\begin{array}{c}\text { Jumlah Wajib } \\
\text { Pajak } \\
\text { Kendaraan } \\
\text { Bermotor Yang } \\
\text { Menunggak }\end{array}$ & $\begin{array}{c}\text { Potensi Yang } \\
\text { Diperoleh Dari } \\
\text { Wajib Pajak Yang } \\
\text { Menunggak }\end{array}$ & Persentase \\
\hline 2015 & 81.802 & 65.169 & 16.633 & 13.390 & Rp. 32.008.638.984 & $16 \%$ \\
\hline 2016 & 84.764 & 65.545 & 19.219 & 12.977 & Rp. 36.378.187.211 & $15 \%$ \\
\hline 2017 & 103.363 & 72.423 & 30.940 & 16.534 & Rp. 38.852.362.021 & $16 \%$ \\
\hline 2018 & 115.483 & 83.502 & 31.981 & 28.418 & Rp. 88.504 .802 .648 & $25 \%$ \\
\hline 2019 & 116.268 & 81.931 & 34.337 & 24.437 & Rp. 85.767 .590 .896 & $21 \%$ \\
\hline
\end{tabular}

Sumber : Kantor Bapenda Tahun 2020.

Berdasarkan tabel 1 diatas, dapat dilihat semakin meningkat jumlah wajib pajak kendaraan bermotor tiap tahunnya, tidak diimbangi dengan tingkat kepatuhan wajib pajak dalam membayar pajak kendaraannya. Terbukti berdasakan data tahun 2015 sampai dengan 2019 jumlah wajib pajak yang menunggak juga ikut meningkat. Ketidakpatuhan wajib pajak kendaraan bermotor dalam melakukan kewajibannya dalam membayar pajak dapat dipengaruhi oleh beberapa faktor, diantaranya yaitu kurangnya kesadaran wajib pajak dalam membayar pajak dan kurangnya pemahaman sanksi pajak yang diterima bila tidak melakukan kewajibannya.

Penelitian ini bertujan untuk menguji pengaruh kesadaran wajib pajak dan sanksi pajak berpengaruh terhadap kepatuhan wajib pajak kendaraan bermotor di Kota Kendari.

\section{TINJAUAN PUSTAKA}

Menurut Kamus Umum Bahasa Indonesia, istilah kepatuhan adalah Kepatuhan berarti tunduk atau patuh pada ajaran dalam perpajakan kita dapat memberi pengertian bahwa kepatuhan perpajakan merupakan ketaatan, tunduk, dan patuh, serta melaksanakan ketentuan perpajakan. Kepatuhan wajib pajak kendaraan bermotor yaitu dimana wajib pajak memenuhi kewajiban perpajakannya dan melaksanakan hak perpajakan dengan baik dan benar sesuai dengan peraturan dan Undang-Undang pajak yang berlaku. Sedangkan ketidakpatuhan wajib pajak kendaraan bermotor adalah dimana wajib pajak tidak memenuhi kewajiban perpajakannya dan tidak melaksanakan hak perpajakan dengan baik dan benar berdasarkan peraturan dan Undang-Undang yang berlaku. Ilhamsyah dkk. (2016), Kepatuhan wajib pajak Kendaraan Bermotor yaitu dimana Wajib Pajak memenuhi kewajiban perpajakannya dan melaksanakan hak perpajakan dengan baik dan benar sesuai dengan peraturan dan Undang-Undang pajak yang berlaku.

Kesadaran wajib pajak adalah suatu kondisi dimana Wajib Pajak mengetahui, mengakui, menghargai dan menaati ketentuan perpajakan yang berlaku serta memiliki kesungguhan dan keinginan untuk memenuhi kewajiban pajaknya. Menurut Mutia (2014) kesadaran Wajib Pajak akan perpajakan adalah dimana rasa yang timbul dalam diri Wajib Pajak atas kewajibannya membayar pajak dengan ikhlas tanpa adanya unsur paksaan. Kesadaran Wajib Pajak merupakan sebuah itikad baik seseorang untuk memenuhi kewajiban membayar pajak berdasarkan hati nuraninya yang tulus ikhlas (Susilawati dan Budiarthi, 2013). Penelitian yang dilakukan oleh Agnes (2015) menyatakan bahwa kesadaran wajib pajak berpengaruh terhadap kepatuhan wajib pajak kendaraan bermotor. Penelitian ini didukung oleh Dian dan Siti (2018) dan Anis (2019).

Sanksi pajak adalah suatu tindakan berupa hukuman yang diberikan kepada orang yang melanggar peraturan. Peraturan atau undang-undang merupakan rambu-rambu bagi 
seseorang untuk melakukan sesuatu mengenai apa yang harus dilakukan dan apa yang seharusnya tidak dilakukan. Menurut Resmi (2018), sanksi perpajakan terjadi karena terdapat pelanggaran terhadap peraturan perundang-undangan perpajakan, sehingga apabila terjadi pelanggaran maka wajib pajak dihukum dengan indikasi kebijakan perpajakan dan undang-undang perpajakan. Menurut Mardiasmo (2018) sanksi perpajakan merupakan suatu jaminan atau pencegahan (preventif) bahwa ketentuan peraturan perundangundangan perpajakan atau norma perpajakan akan dituruti/ ditaati/ dipatuhi. Dengan kata lain sanksi perpajakan merupakan alat pencegah (preventif) agar Wajib Pajak (WP) tidak melanggar ketentuan-ketentuan dan aturan yang sudah berlaku. Penelitian yang dilakukan oleh Muslikhatul (2015) menyatakan bahwa sanksi pajak berpengaruh terhadap kepatuhan wajib pajak kendaraan bermotor. Penelitian ini didukung oleh Dian dan Siti (2018) dan Anis (2019).

Berdasarkan penjelasan teori diatas, maka hipoyesis yang diajukan sebagai berikut:

H1 : Kesadaran wajib pajak secara parsial berpengaruh terhadap kepatuhan wajib pajak kendaraan bermotor di Kota Kendari

$\mathrm{H} 2$ : Sanksi pajak secara parsial berpengaruh terhadap kepatuhan wajib pajak kendaraan bermotor di Kota Kendari.

H3 : kesadaran wajib pajak dan sanksi pajak secara simultan berpengaruh terhadap kepatuhan wajib pajak kendaraan bermotor di Kota Kendari.

\section{METODE PENELITIAN}

Objek dari penelitian adalah pengaruh kesadaran wajib pajak dan sanksi pajak sebagai variabel independen, terhadap kepatuhan wajib pajak kendaraan bermotor sebagai variabel dependen yang dilakukan di Kota Kendari.

Berdasarkan data yang di peroleh dari Kantor Samsat Kota Kendari, jumlah wajib pajak kendaraan bermotor pada tahun 2019 sebanyak 116.268 wajib pajak. Teknik pengambilan sampel yang digunakan adalah teknik insidental sampling, yaitu wajib pajak yang dalam penelitian di temui oleh peneliti yang secara kebetulan bertemu digunakan sebagai sampel penelitian, dijadikan sumber data jika dipandang cocok menurut peneliti. Peneliti menggunakan teknik sampel ini karena memudahkan peneliti dalam melaksanakan proses riset sehingga tidak menetapkan kriteria khusus atau rumit dalam pengambilan sampel. Penentuan sampel ditentukan dengan rumus slovin dan menghasilkan sampel sebanyak 100 orang. Adapun karakteristik responden yang dimasukkan dalam penelitian ini meliputi berdasarkan jenis kelamin, usia, pekerjaan, jenis kendaraan, melakukan tunggakan, lama tunggakan, jumlah tunggakan dan denda yang dibayarkan.

Jenis data kualitatif dalam penelitian ini, berupa uraian penjelasan dari variabel dan pernyataan dalam kuesioner yang akan diklasifikasikan ke dalam kategori menggunakan skala likert. Jenis data kuantitatif dalam penelitian ini adalah jawaban responden atas pertanyaan kuesioner yang diukur menggunakan skor dari skala Likert.

Sumber data primer yang digunakan dalam penelitian ini yaitu data yang bersumber dari wajib pajak yang dikumpulkan melalui kuesioner. Data sekunder dalam penelitian ini, yaitu profil dan sejarah Kantor Samsat Kota Kendari serta data yang diambil dari jurnal, skripsi, dan buku-buku referensi.

Metode yang digunakan dalam penelitian ini yaitu kuesioner dibuat berdasarkan indikator, dan merujuk pada penelitian terdahulu serta menyesuaikan dengan keadaan objek penelitian. wawancara yang dilakukan pada studi pendahuluan untuk fenomena penelitian. Dokumentasi, merupakan teknik penelitian dimana mengumpulkan data- data yang diperlukan sehubungan dengan penelitian misalnya struktur organisasi, tugas dan fungsi struktur organisasi, dan visi misi Kantor Samsat Kota Kendari. Tinjauan kepustakaan (library research), metode ini dilakukan dengan mempelajari teori-teori dan konsep-konsep 
yang sehubungan dengan masalah yang diteliti penulis pada buku-buku, makalah, dan jurnal guna memperoleh landasan teoritis yang memadai untuk melakukan pembahasan.

Metode analisis data yang digunakan yaitu sebagai berikut :

1. Analisis Deskriptif variabel penelitian bertujuan untuk menginterprestasikan mengenai distribusi frekuensi jawaban responden. Berdasarkan data primer yang diperoleh, distribusi frekuensi masing masing jawaban dikelompokkan sesuai dengan tabel dan item jawaban. Skala yang digunakan adalah skala likert yang mempunyai skor 1 sampai 5. Dalam memberikan makna penilaian secara empiris variabel penelitian ini mengadopsi prinsip dari pembobotan atau nilai skor jawaban responden yang di klasifikasikan kedalam rentang skala kategori nilai yang disajikan dalam tabel sebagai berikut:

Tabel 2

Penentuan Kategori Rata-Rata Skor Pernyataan Responden Dan Makna Penilaian Secara Deskriptif.

\begin{tabular}{|l|l|l|l|}
\hline No. & $\begin{array}{l}\text { Nilai Rata-Rata } \\
\text { Skor Jawaban }\end{array}$ & Makna Kategori/Interpretasi & Nilai Skor \\
\hline 1 & $1-1,8$ & Sangat rendah/Tidak baik & 1 \\
2 & $>1,8-2,6$ & Rendah/Kurang Baik & 2 \\
3 & $>2,6-3,4$ & Cukup Tinggi/Cukup Baik & 3 \\
4 & $>3,4-4,2$ & Tinggi/Baik & 4 \\
5 & $>4,2$ & Sangat Tinggi/Sangat Baik & 5 \\
\hline
\end{tabular}

Sumber : (Solimun 2017)

2. Analisis regresi linear berganda adalah hubungan secara linear antara dua atau lebih variable independen $(\mathrm{X})$ dengan variable dependen $(\mathrm{Y})$. Berikut model persamaan regresi linear berganda sebagai berikut:

$\mathrm{Y}=\mathrm{a}+\mathrm{b} 1 \mathrm{X} 1+\mathrm{b} 2 \mathrm{X} 2+\mathrm{e}$

Sumber : (Sunyoto 2013)

\begin{tabular}{|c|c|c|}
\hline \multirow[t]{6}{*}{ Keterangan: } & Y & : Kepatuhan wajib pajak kendaraan bermotor \\
\hline & $\mathrm{Xl}$ & : Kesadaran wajib pajak \\
\hline & $\mathrm{X} 2$ & : Sanksi pajak \\
\hline & & : Konstanta \\
\hline & bI dan b2 & : Koefisien regresi \\
\hline & $\mathrm{e}$ & : Variabel lain yang tidak diteliti \\
\hline
\end{tabular}

Pengujian hipotesis dilakukan melalui uji statistik F, uji statistik t dan uji koefisien determinasi. Pengujian dapat dilakukan setelah model regresi bebas dari gejala-gejala asumsi klasik. Pengujian asumsi klasik yang dilakukan dalam penelitian ini meliputi uji autokorelasi, uji normalitas, uji heterokedastisitas dan uji multikolinearitas.

\section{HASIL DAN PEMBAHASAN}

Data penelitian dikumpulkan dengan menyebarkan kuesioner sebanyak 100. Data kuesioner yang kembali berjumlah 88 kuesioner, setelah diperiksa seluruh kuesioner yang kembali diisi dengan lengkap dan layak diolah untuk dijadikan sebagai bahan dalam penelitian ini. Adapun tingkat pengembalian kuesioner disajikan pada tabel berikut : 
Jurnal Akuntansi dan Keuangan (JAK)

Volume 6, No. 1 Februari Tahun 2021

Page: $154-169$

http://ojs.uho.ac.id/index.php/jak-uho/issue/archive

e-ISSN: 2088-4656

Tabel 3

Tingkat Pengembalian Kuesioner

\begin{tabular}{|l|l|}
\hline Keterangan & Jumlah \\
\hline Kuesioner yang dibagi & 100 \\
\hline Kuesioner yang tidak kembali & 12 \\
\hline Kuesioner yang kembali & 88 \\
\hline Kuesioner yang dapat dianalisis & 88 \\
\hline Kuesioner yang tidak dapat dianalisis & - \\
\hline Tingkat pengembalian kuesionetr yang digunakan & $\mathbf{8 8 \%}$ \\
\hline
\end{tabular}

Sumber : Data Primer Diolah tahun 2020

\section{Analasis Deskriptif}

Variabel kesadaran wajib pajak $\left(\mathrm{X}_{1}\right)$ diukur dengan menggunakan 9 butir item pertanyaan dari 3 indikator yaitu Kesadaran adanya hak dan kewajiban wajib pajak $\left(\mathrm{X}_{1.1}\right)$, Kepercayaan masyarakat dalam membayar pajak untuk pembiayaan negara dan daerah $\left(\mathrm{X}_{1.2}\right)$, Dorongan diri sendiri untuk membayar pajak secara suka rela $\left(\mathrm{X}_{1.3}\right)$. Rekapitulasi jawaban atas pernyataan responden diuraikan sebagai berikut:

\section{Tabel 4}

Rekapitulasi Jawaban Responden atas Variabel Kesadaran Wajib Pajak (X1)

\begin{tabular}{|c|c|c|c|c|c|c|c|c|c|c|c|c|}
\hline \multirow{3}{*}{$\begin{array}{l}\text { Item } \\
\text { (Butir) }\end{array}$} & \multicolumn{10}{|c|}{ Frekuensi Jawaban Responden (f) \& Persentase (\%) } & \multirow{3}{*}{$\begin{array}{l}\text { Rata- } \\
\text { rata } \\
\text { Skor }\end{array}$} & \multirow[t]{3}{*}{ Kategori } \\
\hline & \multicolumn{2}{|c|}{ STS (1) } & \multicolumn{2}{|c|}{ TS (2) } & \multicolumn{2}{|c|}{$\mathbf{R}(3)$} & \multicolumn{2}{|c|}{ S (4) } & \multicolumn{2}{|c|}{ SS(5) } & & \\
\hline & $\mathbf{F}$ & $\%$ & $\mathbf{F}$ & $\%$ & $\mathbf{F}$ & $\%$ & $\mathbf{F}$ & $\%$ & $\mathbf{F}$ & $\%$ & & \\
\hline $\mathrm{X} 1.1 .1$ & 0 & 0,00 & 0 & 0,00 & 11 & 12,50 & 49 & 55,68 & 28 & 31,82 & 4,19 & Baik \\
\hline $\mathrm{X} 1.1 .2$ & 0 & 0,00 & 1 & 1,14 & 17 & 19,32 & 56 & 63,64 & 14 & 15,91 & 3,94 & Baik \\
\hline $\mathrm{X} 1.1 .3$ & 0 & 0,00 & 0 & 0,00 & 17 & 19,32 & 49 & 55,68 & 22 & 25,00 & 4,06 & Baik \\
\hline \multicolumn{11}{|c|}{$\begin{array}{l}\text { Rata-rata Indikator Kesadaran Adanya Hak dan Kewajiban Wajib Pajak } \\
\text { (X1.1) }\end{array}$} & 4,06 & Baik \\
\hline X1.2.1 & 0 & 0,00 & 1 & 1,14 & 16 & 18,18 & 55 & 62,50 & 16 & 18,18 & 3,98 & Bai \\
\hline $\mathrm{X} 1.2 .2$ & 0 & 0,00 & 1 & 1,14 & 12 & 13,64 & 60 & 68,18 & 15 & 17,05 & 4,01 & Baik \\
\hline $\mathrm{X} 1.2 .3$ & 0 & 0,00 & 0 & 0,00 & 13 & 14,77 & 58 & 65,91 & 17 & 19,32 & 4,05 & Baik \\
\hline \multicolumn{11}{|c|}{$\begin{array}{l}\text { Rata-rata Indikator Kepercayaan Masyarakat Dalam Membayar Pajak } \\
\text { Untuk Pembiayaan Negara Dan Daerah (X1.2) }\end{array}$} & 4,01 & Baik \\
\hline X1.3.1 & 0 & 0,00 & 2 & 2,27 & 16 & 18,18 & 49 & 55,68 & 21 & 23,86 & 4,01 & Baik \\
\hline $\mathrm{X} 1.3 .2$ & 0 & 0,00 & 0 & 0,00 & 15 & 17,05 & 51 & 57,95 & 22 & 25,00 & 4,08 & Baik \\
\hline X1.3.3 & 0 & 0,00 & 1 & 1,14 & 21 & 23,86 & 53 & 60,23 & 13 & 14,77 & 3,89 & Baik \\
\hline \multicolumn{11}{|c|}{$\begin{array}{l}\text { Rata-rata Indikator Dorongan Diri Sendiri Untuk Membayar Pajak Secara } \\
\text { Suka Rela (X1.3) }\end{array}$} & 3,99 & Baik \\
\hline \multicolumn{11}{|c|}{ Rata-rata Variabel Kesadaran Wajib Pajak (X1) } & 4,02 & Baik \\
\hline
\end{tabular}

Sumber: Data Primer diolah tahun 2020

Berdasarkan distribusi skor jawaban responden atas variabel kesadaran wajib pajak $\left(\mathrm{X}_{1}\right)$ pada tabel 4 dapat diketahui bahwa dari 88 orang responden yang diteliti, terkait pernyataan responden pada variabel kesadaran wajib pajak $\left(\mathrm{X}_{1}\right)$ menurut tanggapan responden adalah baik. Hal ini terlihat dari nilai persepsi dengan nilai rata-rata sebesar 4,02 termasuk dalam kategori baik. Dari persepsi responden tersebut tampak bahwa indikator kesadaran adanya hak dan kewajiban wajib pajak $\left(\mathrm{X}_{1.1}\right)$ mendapat perhatian lebih kuat dibandingkan dengan indikator lainnya, yaitu kepercayaan masyarakat dalam membayar pajak untuk pembiayaan negara dan daerah $\left(X_{1.2}\right)$ dan dorongan diri sendiri untuk membayar pajak secara suka rela $\left(\mathrm{X}_{1.3}\right)$.

Variabel sanksi pajak $\left(\mathrm{X}_{2}\right)$ diukur dengan menggunakan 9 butir item pertanyaan dari 3 indikator yaitu Keterlambatan membayar pajak harus dikenakan sanksi $\left(\mathrm{X}_{2.1}\right)$, Tingkat penerapan sanksi pajak $\left(\mathrm{X}_{2.2}\right)$, Sanksi digunakan untuk meningkatkan kepatuhan wajib pajak $\left(\mathrm{X}_{2.3}\right)$. Rekapitulasi jawaban atas pernyataan responden diuraikan sebagai berikut: 
Tabel 5

Rekapitulasi Jawaban Responden atas Variabel Sanksi Pajak (X2)

\begin{tabular}{|c|c|c|c|c|c|c|c|c|c|c|c|c|}
\hline \multirow{3}{*}{$\begin{array}{l}\text { Item } \\
\text { (Butir) }\end{array}$} & \multicolumn{10}{|c|}{ Frekuensi Jawaban Responden (f) \& Persentase (\%) } & \multirow{3}{*}{$\begin{array}{l}\text { Rata- } \\
\text { rata } \\
\text { Skor }\end{array}$} & \multirow[t]{3}{*}{ Kategori } \\
\hline & \multicolumn{2}{|c|}{ STS (1) } & \multicolumn{2}{|c|}{ TS (2) } & \multicolumn{2}{|c|}{$\mathbf{R}(3)$} & \multicolumn{2}{|c|}{ S (4) } & \multicolumn{2}{|c|}{$\mathbf{S S}(\mathbf{5})$} & & \\
\hline & $\mathbf{F}$ & $\%$ & $\mathbf{F}$ & $\%$ & $\mathbf{F}$ & $\%$ & $\mathbf{F}$ & $\%$ & $\mathbf{F}$ & $\%$ & & \\
\hline X2.1.1 & 0 & 0,00 & 0 & 0,00 & 17 & 19,32 & 48 & 54,55 & 23 & 26,14 & 4,07 & Baik \\
\hline $\mathrm{X} 2.1 .2$ & 0 & 0,00 & 0 & 0,00 & 15 & 17,05 & 49 & 55,68 & 24 & 27,27 & 4,10 & Baik \\
\hline $\mathrm{X} 2.1 .3$ & 0 & 0,00 & 0 & 0,00 & 16 & 18,18 & 52 & 59,09 & 20 & 22,73 & 4,05 & Baik \\
\hline \multicolumn{11}{|c|}{$\begin{array}{l}\text { Rata-rata Indikator Keterlambatan membayar pajak harus dikenakan } \\
\text { sanksi (X2.1) }\end{array}$} & 4,07 & Baik \\
\hline $\mathrm{X} 2.2 .1$ & 0 & 0,00 & 1 & 1,14 & 15 & 17,05 & 51 & 57,95 & 21 & 23,86 & 4,05 & Baik \\
\hline $\mathrm{X} 2.2 .2$ & 0 & 0,00 & 0 & 0,00 & 19 & 21,59 & 50 & 56,82 & 19 & 21,59 & 4,00 & Baik \\
\hline $\mathrm{X} 2.2 .3$ & 0 & 0,00 & 7 & 7,95 & 22 & 25,00 & 44 & 50,00 & 15 & 17,05 & 3,76 & Baik \\
\hline \multicolumn{11}{|c|}{ Rata-rata Indikator Tingkat penerapan sanksi pajak (X2.2) } & 3,94 & Baik \\
\hline $\mathrm{X} 2.3 .1$ & 0 & 0,00 & 0 & 0,00 & 17 & 19,32 & 41 & 46,59 & 30 & 34,09 & 4,15 & Baik \\
\hline $\mathrm{X} 2.3 .2$ & 0 & 0,00 & 3 & 3,41 & 26 & 29,55 & 32 & 36,36 & 27 & 30,68 & 3,94 & Baik \\
\hline $\mathrm{X} 2.3 .3$ & 0 & 0,00 & 0 & 0,00 & 20 & 22,73 & 48 & 54,55 & 20 & 22,73 & 4,00 & Baik \\
\hline \multicolumn{11}{|c|}{$\begin{array}{l}\text { Rata-rata Indikator Sanksi digunakan untuk meningkatkan kepatuhan } \\
\text { wajib pajak (X2.3) }\end{array}$} & $\mathbf{4 , 0 3}$ & Baik \\
\hline \multicolumn{11}{|c|}{ Rata-rata Variabel Sanksi Pajak (X2) } & 4,01 & Baik \\
\hline
\end{tabular}

Sumber: Data Primer diolah tahun 2020

Berdasarkan distribusi skor jawaban responden atas variabel sanksi pajak $\left(\mathrm{X}_{2}\right)$ pada tabel 5 dapat diketahui bahwa dari 88 orang responden yang diteliti terkait pernyataan responden pada variabel sanksi pajak $\left(\mathrm{X}_{2}\right)$ menurut tanggapan responden adalah baik. Hal ini terlihat nilai persepsi dengan nilai rata-rata sebesar 4,01 termasuk dalam kategori baik. Dari persepsi responden tersebut tampak bahwa indikator Keterlambatan membayar pajak harus dikenakan sanksi $\left(\mathrm{X}_{2.1}\right)$ mendapat perhatian yang lebih kuat dibandingkan dengan indikator lainnya yaitu, Tingkat penerapan sanksi pajak $\left(\mathrm{X}_{2.2}\right)$ dan Sanksi digunakan untuk meningkatkan kepatuhan wajib pajak $\left(\mathrm{X}_{2.3}\right)$.

Variabel kepatuhan wajib pajak kendaraan bermotor (Y) diukur dengan menggunakan 18 butir item pertanyaan dari 6 indikator yaitu, Memenuhi kewajiban pajak sesuai ketentuan yang berlaku ( $\mathrm{Y}_{1.1}$, Wajib pajak tidak mempunyai tunggakan pajak ( $\left.\mathrm{Y}_{1.2}\right)$, Membayar pajak tepat pada waktunya $\left(\mathrm{Y}_{1.3}\right)$, Wajib pajak memenuhi persyaratan dalam membayarkan pajaknya $\left(\mathrm{Y}_{1.4}\right)$, Wajib pajak dapat mengetahui jatuh tempo pembayaran ( $\left.\mathrm{Y}_{1.5}\right)$, dan Tidak pernah melanggar ketentuan peraturan ( $\left.\mathrm{Y}_{1.6}\right)$. Rekapitulasi jawaban atas pernyataan responden diuraikan sebagai berikut:

\section{Tabel 6}

Rekapitulasi Jawaban Responden atas Variabel Kepatuhan Wajib pajak Kendaraan Bermotor (Y)

\begin{tabular}{|c|c|c|c|c|c|c|c|c|c|c|c|c|}
\hline \multirow{3}{*}{$\begin{array}{l}\text { Item } \\
\text { (Butir) }\end{array}$} & \multicolumn{10}{|c|}{ Frekuensi Jawaban Responden (f) \& Persentase (\%) } & \multirow{3}{*}{$\begin{array}{l}\text { Rata- } \\
\text { rata } \\
\text { Skor }\end{array}$} & \multirow[t]{3}{*}{ Kategori } \\
\hline & \multicolumn{2}{|c|}{ STS (1) } & \multicolumn{2}{|c|}{ TS (2) } & \multicolumn{2}{|c|}{$\mathbf{R}(3)$} & \multicolumn{2}{|c|}{$\mathrm{S}(4)$} & \multicolumn{2}{|c|}{ SS(5) } & & \\
\hline & $\mathbf{F}$ & $\%$ & $\mathbf{F}$ & $\%$ & $\mathbf{F}$ & $\%$ & $\mathbf{F}$ & $\%$ & $\mathbf{F}$ & $\%$ & & \\
\hline Y.1.1 & 0 & 0,00 & 0 & 0,00 & 13 & 14,77 & 44 & 50,00 & 31 & 35,23 & 4,20 & Sangat Baik \\
\hline Y.1.2 & 0 & 0,00 & 2 & 2,27 & 10 & 11,36 & 52 & 59,09 & 24 & 27,27 & 4,11 & Baik \\
\hline Y.1.3 & 0 & 0,00 & 0 & 0,00 & 9 & 10,23 & 43 & 48,86 & 36 & 40,91 & $\mathbf{4 , 3 1}$ & Sangat Baik \\
\hline \multicolumn{11}{|c|}{$\begin{array}{l}\text { Rata-rata Indikator Memenuhi kewajiban pajak sesuai ketentuan yang } \\
\text { berlaku (Y.1) }\end{array}$} & 4,21 & Sangat Baik \\
\hline Y.2.1 & 0 & 0,00 & 0 & 0,00 & 11 & 12,50 & 45 & 51,14 & 32 & 36,36 & 4,24 & Sangat Baik \\
\hline Y.2.2 & 0 & 0,00 & 1 & 1,14 & 17 & 19,32 & 51 & 57,95 & 19 & 21,59 & 4,00 & Baik \\
\hline Y.2.3 & 1 & 1,14 & 2 & 2,27 & 23 & 26,14 & 45 & 51,14 & 17 & 19,32 & 3,85 & Baik \\
\hline \multicolumn{11}{|c|}{ Rata-rata Indikator Wajib pajak tidak mempunyai tunggakan pajak (Y.2) } & 4,03 & Baik \\
\hline Y.3.1 & 0 & 0,00 & 3 & 3,41 & 10 & 11,36 & 51 & 57,95 & 24 & 27,27 & 4,09 & Baik \\
\hline Y.3.2 & 0 & 0,00 & 0 & 0,00 & 9 & 10,23 & 43 & 48,86 & 36 & 40,91 & 4,31 & Sangat Baik \\
\hline
\end{tabular}


Jurnal Akuntansi dan Keuangan (JAK)

Volume 6, No. 1 Februari Tahun 2021

Page: 154 - 169

http://ojs.uho.ac.id/index.php/iak-uho/issue/archive

e-ISSN: 2088-4656

\begin{tabular}{|c|c|c|c|c|c|c|c|c|c|c|c|c|}
\hline Y.3.3 & 0 & 0,00 & 1 & 1,14 & 16 & 18,18 & 53 & 60,23 & 18 & 20,45 & 4,00 & Baik \\
\hline \multicolumn{11}{|c|}{ Rata-rata Indikator Membayar pajak tepat pada waktunya (Y.3) } & 4,13 & Baik \\
\hline Y.4.1 & 0 & 0,00 & 3 & 3,41 & 20 & 22,73 & 44 & 50,00 & 21 & 23,86 & 3,94 & Baik \\
\hline Y.4.2 & 0 & 0,00 & 0 & 0,00 & 14 & 15,91 & 50 & 56,82 & 24 & 27,27 & 4,11 & Baik \\
\hline Y.4.3 & 0 & 0,00 & 2 & 2,27 & 21 & 23,86 & 46 & 52,27 & 19 & 21,59 & 3,93 & Baik \\
\hline \multicolumn{11}{|c|}{$\begin{array}{l}\text { Rata-rata Indikator Wajib pajak memenuhi persyaratan } \\
\text { membayarkan pajaknya (Y.4) }\end{array}$} & 4,00 & Baik \\
\hline Y.5.1 & 0 & 0,00 & 0 & 0,00 & 26 & 29,55 & 45 & 51,14 & 17 & 19,32 & 3,90 & Baik \\
\hline Y.5.2 & 0 & 0,00 & 1 & 1,14 & 18 & 20,45 & 47 & 53,41 & 22 & 25,00 & 4,02 & Baik \\
\hline Y.5.3 & 1 & 1,14 & 2 & 2,27 & 26 & 29,55 & 49 & 55,68 & 10 & 11,36 & 3,74 & Baik \\
\hline \multicolumn{11}{|c|}{$\begin{array}{l}\text { Rata-rata Indikator Wajib pajak dapat mengetahui jatuh tempo } \\
\text { pembayaran (Y.5) }\end{array}$} & 3,89 & Baik \\
\hline Y.6.1 & 0 & 0,00 & 1 & 1,14 & 20 & 22,73 & 35 & 39,77 & 32 & 36,36 & 4,11 & Baik \\
\hline Y.6.2 & 0 & 0,00 & 4 & 4,55 & 24 & 27,27 & 31 & 35,23 & 29 & 32,95 & 3,97 & Baik \\
\hline Y.6.3 & 0 & 0,00 & 2 & 2,27 & 24 & 27,27 & 43 & 48,86 & 19 & 21,59 & 3,90 & Baik \\
\hline \multicolumn{11}{|c|}{ Rata-rata Indikator Tidak pernah melanggar ketentuan peraturan (Y.6) } & 3,99 & Baik \\
\hline \multicolumn{11}{|c|}{ Rata-rata Variabel Kepatuhan Wajib Pajak Kendaraan Bermotor (Y) } & 4,04 & Baik \\
\hline
\end{tabular}

Sumber: Data Primer diolah tahun 2020

Berdasarkan distribusi skor jawaban responden atas variabel kepatuhan wajib pajak kendaraan bermotor (Y) pada tabel 6 dapat diketahui bahwa dari 88 orang responden yang diteliti, menunjukkan kepatuhan wajib pajak kendaraan bermotor (Y) menurut tanggapan responden adalah baik. Hal ini terlihat nilai persepsi dengan nilai rata-rata sebesar 4,04 termasuk dalam kategori baik. Dari persepsi responden tersebut tampak bahwa indikator Memenuhi kewajiban pajak sesuai ketentuan yang berlaku $\left(\mathrm{Y}_{1.1}\right)$ mendapat perhatian yang lebih kuat dibandingkan dengan indikator lainnya yaitu, Wajib pajak tidak mempunyai tunggakan pajak ( $\mathrm{Y}_{1.2}$ ), Membayar pajak tepat pada waktunya ( $\mathrm{Y}_{1.3}$ ), Wajib pajak memenuhi persyaratan dalam membayarkan pajaknya $\left(\mathrm{Y}_{1.4}\right)$, Wajib pajak dapat mengetahui jatuh tempo pembayaran $\left(\mathrm{Y}_{1.5}\right)$, dan Tidak pernah melanggar ketentuan peraturan $\left(\mathrm{Y}_{1.6}\right)$.

Hasil koefisien korelasi dan cronbach alpha untuk menguji validitas dan reabilitas penggunakan item pernyataan dari indikator varibel sebagai berikut :

\section{Tabel 7}

Rekapitulasi Hasil Uji Validitas dan Reliabilitas

\begin{tabular}{|c|c|c|c|c|c|c|c|}
\hline Variabel & Indikator Variabel & Item & $\begin{array}{c}\text { Koefisisen } \\
\text { korelasi }\end{array}$ & Sig. & Ket. & $\begin{array}{c}\text { Cronbach } \\
\text { Alpha }\end{array}$ & Ket. \\
\hline \multirow{9}{*}{$\begin{array}{l}\text { Kesadararan } \\
\text { Wajib Pajak } \\
\text { (X1) }\end{array}$} & \multirow{3}{*}{$\begin{array}{l}\text { Kesadaran adanya hak } \\
\text { dan kewajiban wajib } \\
\text { pajak (X1.1) }\end{array}$} & $\mathrm{X} 1.1 .1$ & 0,840 & 0,00 & \multirow{3}{*}{ Valid } & \multirow{3}{*}{0.844} & \multirow{3}{*}{ Reliabel } \\
\hline & & $\mathrm{X} 1.1 .2$ & 0,821 & 0,00 & & & \\
\hline & & $\mathrm{X} 1.1 .3$ & 0,873 & 0,00 & & & \\
\hline & \multirow{3}{*}{$\begin{array}{l}\text { Kepercayaan } \\
\text { masyarakat dalam } \\
\text { membayar pajak untuk } \\
\text { pembiayaan negara dan } \\
\text { daerah (X1.2) }\end{array}$} & $\mathrm{X} 1.2 .1$ & 0,906 & 0,00 & \multirow{3}{*}{ Valid } & \multirow{3}{*}{0,855} & \multirow{3}{*}{ Reliabel } \\
\hline & & $\mathrm{X} 1.2 .2$ & 0,914 & 0,00 & & & \\
\hline & & $\mathrm{X} 1.2 .3$ & 0,808 & 0,00 & & & \\
\hline & \multirow{3}{*}{$\begin{array}{l}\text { Dorongan diri sendiri } \\
\text { untuk membayar pajak } \\
\text { secara suka rela }(\mathrm{X} 1.3)\end{array}$} & $\mathrm{X} 1.3 .1$ & 0,847 & 0,00 & \multirow{3}{*}{ Valid } & \multirow{3}{*}{0,836} & \multirow{3}{*}{ Reliabel } \\
\hline & & $\mathrm{X} 1.3 .2$ & 0,889 & 0,00 & & & \\
\hline & & $\mathrm{X} 1.3 .3$ & 0,731 & 0,00 & & & \\
\hline \multirow{9}{*}{$\begin{array}{l}\text { Sanksi Pajak } \\
\text { (X2) }\end{array}$} & \multirow{3}{*}{$\begin{array}{l}\text { Keterlambatan } \\
\text { membayar pajak harus } \\
\text { dikenakan sanksi (X2.1) }\end{array}$} & $\mathrm{X} 2.1 .1$ & 0,882 & 0,00 & \multirow{3}{*}{ Valid } & \multirow{3}{*}{0,858} & \multirow{3}{*}{ Reliabel } \\
\hline & & $\mathrm{X} 2.1 .2$ & 0,933 & 0,00 & & & \\
\hline & & $\mathrm{X} 2.1 .3$ & 0,840 & 0,00 & & & \\
\hline & \multirow{3}{*}{$\begin{array}{l}\text { Tingkat penerapan } \\
\text { sanksi pajak }(\mathrm{X} 2.2)\end{array}$} & $\mathrm{X} 2.2 .1$ & 0,896 & 0,00 & \multirow{3}{*}{ Valid } & \multirow{3}{*}{0,855} & \multirow{3}{*}{ Reliabel } \\
\hline & & $\mathrm{X} 2.2 .2$ & 0,883 & 0,00 & & & \\
\hline & & $\mathrm{X} 2.2 .3$ & 0,869 & 0,00 & & & \\
\hline & \multirow{3}{*}{$\begin{array}{l}\text { Sanksi digunakan untuk } \\
\text { meningkatkan } \\
\text { kepatuhan wajib pajak } \\
\text { (X2.3) }\end{array}$} & $\mathrm{X} 2.3 .1$ & 0,853 & 0,00 & \multirow{3}{*}{ Valid } & \multirow{3}{*}{0,851} & \multirow{3}{*}{ Reliabel } \\
\hline & & $\mathrm{X} 2.3 .2$ & 0,899 & 0,00 & & & \\
\hline & & $\mathrm{X} 2.3 .3$ & 0,846 & 0,00 & & & \\
\hline
\end{tabular}


Jurnal Akuntansi dan Keuangan (JAK)

Volume 6, No. 1 Februari Tahun 2021

Page: 154 - 169

http://ojs.uho.ac.id/index.php/jak-uho/issue/archive

e-ISSN: 2088-4656

\begin{tabular}{|c|c|c|c|c|c|c|c|}
\hline \multirow{18}{*}{$\begin{array}{l}\text { Kepatuhan } \\
\text { Wajib Pajak } \\
\text { Kendaraan } \\
\text { Bermotor } \\
\text { (Y) }\end{array}$} & Memenuhi kewajiban & Y.1.1 & 0,949 & 0,00 & \multirow{3}{*}{ Valid } & \multirow{3}{*}{0,868} & \multirow{3}{*}{ Reliabel } \\
\hline & \multirow{2}{*}{$\begin{array}{l}\text { pajak sesuai ketentuan } \\
\text { yang berlaku (Y.1) }\end{array}$} & Y.1.2 & 0,915 & 0,00 & & & \\
\hline & & Y.1.3 & 0,883 & 0,00 & & & \\
\hline & \multirow{3}{*}{$\begin{array}{l}\text { Wajib pajak tidak } \\
\text { mempunyai tunggakan } \\
\text { pajak (Y.2) }\end{array}$} & Y.2.1 & 0,865 & 0,00 & \multirow{3}{*}{ Valid } & \multirow{3}{*}{0,858} & \multirow{3}{*}{ Reliabel } \\
\hline & & Y.2.2 & 0,905 & 0,00 & & & \\
\hline & & Y.2.3 & 0,887 & 0,00 & & & \\
\hline & \multirow{3}{*}{$\begin{array}{l}\text { Membayar pajak tepat } \\
\text { pada waktunya (Y.3) }\end{array}$} & Y.3.1 & 0,925 & 0,00 & \multirow{3}{*}{ Valid } & \multirow{3}{*}{0,862} & \multirow{3}{*}{ Reliabel } \\
\hline & & Y.3.2 & 0,866 & 0,00 & & & \\
\hline & & Y.3.3 & 0,897 & 0,00 & & & \\
\hline & \multirow{3}{*}{$\begin{array}{l}\text { Wajib pajak memenuhi } \\
\text { persyaratan dalam } \\
\text { membayarkan pajaknya } \\
\text { (Y.4) }\end{array}$} & Y.4.1 & 0,901 & 0,00 & \multirow{3}{*}{ Valid } & \multirow{3}{*}{0,844} & \multirow{3}{*}{ Reliabel } \\
\hline & & Y.4.2 & 0,848 & 0,00 & & & \\
\hline & & Y.4.3 & 0,787 & 0,00 & & & \\
\hline & \multirow{3}{*}{$\begin{array}{l}\text { Wajib pajak dapat } \\
\text { mengetahui jatuh tempo } \\
\text { pembayaran (Y.5) }\end{array}$} & Y.5.1 & 0,893 & 0,00 & \multirow{3}{*}{ Valid } & \multirow{3}{*}{0,857} & \multirow{3}{*}{ Reliabel } \\
\hline & & Y.5.2 & 0,906 & 0,00 & & & \\
\hline & & Y.5.3 & 0,847 & 0,00 & & & \\
\hline & \multirow{3}{*}{$\begin{array}{l}\text { Tidak pernah melanggar } \\
\text { ketentuan peraturan } \\
\text { (Y.6) }\end{array}$} & Y.6.1 & 0,897 & 0,00 & \multirow{3}{*}{ Valid } & \multirow{3}{*}{0,858} & \multirow{3}{*}{ Reliabel } \\
\hline & & Y.6.2 & 0,912 & 0,00 & & & \\
\hline & & Y.6.3 & 0,845 & 0,00 & & & \\
\hline
\end{tabular}

Sumber: Data Primer diolah tahun 2020

Tabel 4.12 menyatakan bahwa pernyataan-pernyataan dalam kuesioner merupakan pernyataan yang valid dan reliabel. Keputusan ini diambil karena nilai korelasi pearson > 0,30 dengan tingkat signifikan $<0,05$ dan nilai koefisien korelasi dari hasil cronbach alpha $>0,60$. Sehingga dapat disimpulkan bahwa semua item pernyataan yang digunakan sebagai instrument dalam penelitian ini adalah valid dan reliabel, atau dapat dikatakan kuesioner yang digunakan layak dijadikan sebagai instrument untuk melakukan pengukuran setiap variabel.

\section{Uji Asumsi Klasik}

Uji normalitas dilakukan Untuk menguji nomalitas ini dapat diketahui dari tampilan grafik Normal Probability Plot (P-P Plot Test) dan grafik histogram.

\section{Gambar 1}

Normal Probability Plot
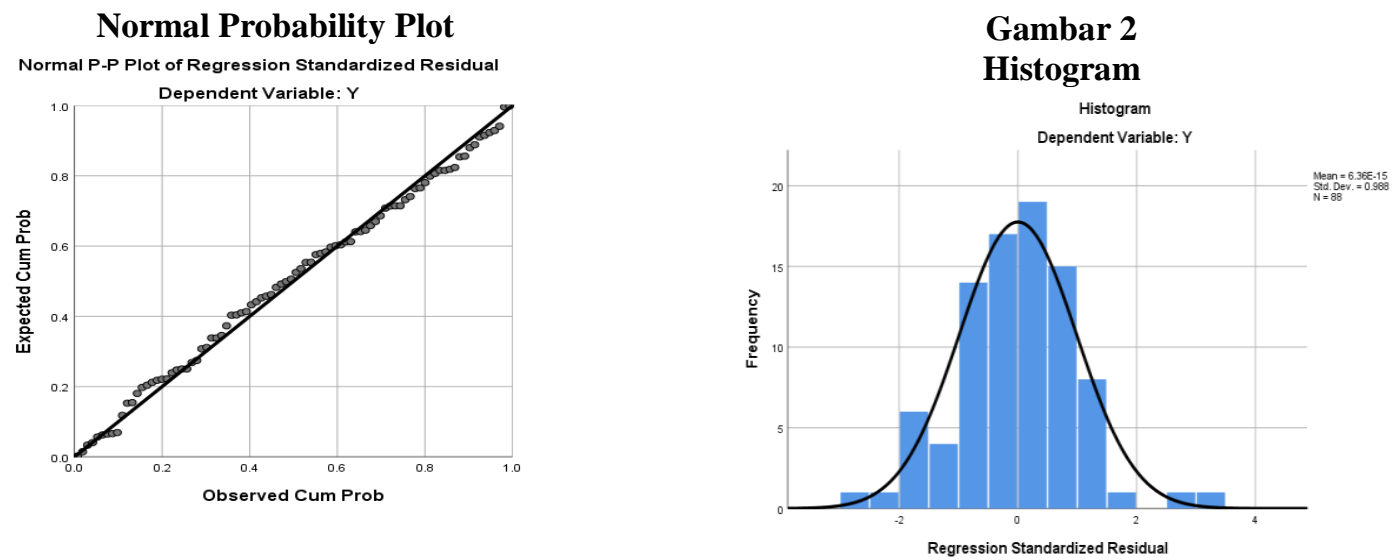

Sumber : Data Primer Diolah 2020.

Gambar 1 normal probability plot di atas, terlihat bahwa titik-titik menyebar di sekitar garis diagonal, serta penyebarannya mengikuti arah garis diagonal. Sehingga model regresi layak dipakai untuk prediksi kepatuhan wajib pajak kendaraan bermotor di Kota Kendari berdasarkan masukan variabel bebasnya.

Gambar 2 histogram diatas, tampak bahwa residual terdistribusi secara normal ditunjukkan dengan pola berbentuk simetris tidak melenceng ke kanan atau ke kiri. Dengan demikian model regresi telah memenuhi asumsi normal. 
Jurnal Akuntansi dan Keuangan (JAK)

Volume 6, No. 1 Februari Tahun 2021

Page: 154 - 169

http://ojs.uho.ac.id/index.php/iak-uho/issue/archive

e-ISSN: 2088-4656

Uji multikolinearitas bertujuan untuk menguji apakah dalam model regresi ditemukan adanya korelasi antar variabel bebas. Apabila angka tolerance $>0,10$ dan VIF $<10$ maka menunjukkan tidak terjadinya multikonearitas dalam model regresi seperti pada tabel berikut :

Tabel 8

\begin{tabular}{|c|c|c|c|c|c|c|c|}
\hline \multicolumn{8}{|c|}{ Hasil Uji Multikolinearitas } \\
\hline \multirow[b]{2}{*}{ Model } & \multicolumn{2}{|c|}{$\begin{array}{l}\text { Unstandardized } \\
\text { Coefficients }\end{array}$} & $\begin{array}{l}\text { Standardized } \\
\text { Coefficients }\end{array}$ & \multirow[b]{2}{*}{$\mathrm{t}$} & \multirow[b]{2}{*}{ Sig. } & \multicolumn{2}{|c|}{ Collinearity Statistics } \\
\hline & $\mathrm{B}$ & Std. Error & Beta & & & Tolerance & VIF \\
\hline$\overline{\text { (Constant) }}$ & .215 & .252 & & .852 & .397 & & \\
\hline $\mathrm{X} 1$ & .341 & .096 & .294 & 3.557 & .001 & .417 & 2.396 \\
\hline $\mathrm{X} 2$ & .612 & .081 & .625 & 7.575 & .000 & .417 & 2.396 \\
\hline
\end{tabular}

Sumber: Data Primer diolah tahun 2020

Tabel 8 menunjukkan bahwa angka tolerance untuk masing-masing variabel dalam penelitian ini berada diatas 0,10 dan nilai VIF berada dibawah 10. Hal ini menunjukkan bahwa tidak ada kolerasi antar variabel bebas sehingga dapat disimpulkan tidak terjadi multikonearitas.

Uji autokorelasi, untuk mendeteksi adanya autokorelasi dapat dilihat dari nilai Durbin-Watson (D-W) seperti pada tabel sebagai berikut :

\section{Tabel 9}

\section{Hasil Uji Autokorelasi}

\begin{tabular}{|c|c|c|c|c|c|}
\hline Model & $\mathrm{R}$ & R Square & $\begin{array}{l}\text { Adjusted } \\
\text { Square }\end{array}$ & ${ }^{\mathrm{R}}$ Std. Error of the Estimate & Durbin-Watson \\
\hline 1 & $.871^{\mathrm{a}}$ & .758 & .752 & .24149 & 1.909 \\
\hline
\end{tabular}

Sumber: Data Primer diolah tahun 2020

Berdasakan output summary sebagaimana pada angka Durbin-Watson (D-W) adalah 1.909, dimana angka tersebut berada diantara nilai du sampai 4-du yaitu 1.69990 < $1.909<2,3001$ yang berarti tidak terjadi autokorelasi.

Uji heteroskedastisitas bertujuan untuk menguji apakah suatu model regresi terjadi ketidaksamaan varian dari residual satu pengamatan kepengamatan lain. Homokedastisitas dari variabel bebas terhadap variabel terikat terpenuhi apabila nilai residual dan nilai prediksinya tidak membentuk pola tertentu dan menjauhi angka skala 0 . Hasil analisis data menunjukkan diagram pancar yang dihasilkan sebagai berikut :

\section{Gambar 3}

\section{Hasil Uji Heterokedastisitas}

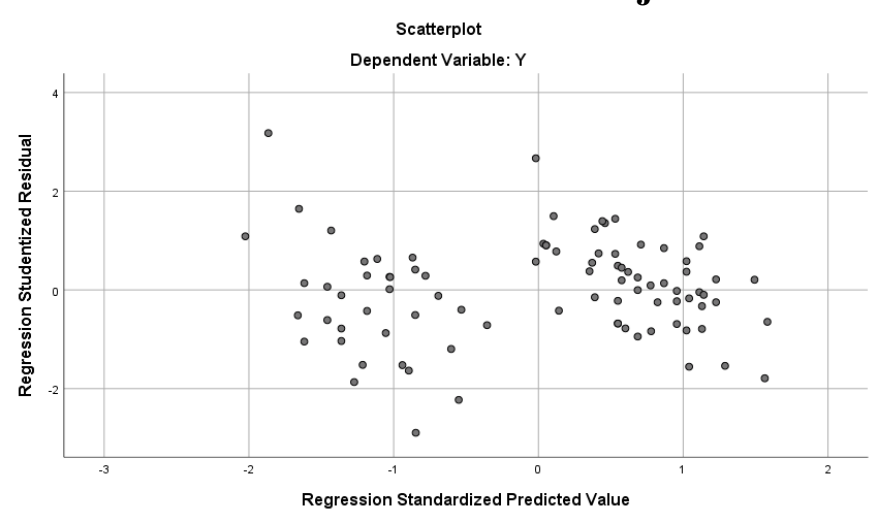

Sumber: Data Primer diolah 2020 
Jurnal Akuntansi dan Keuangan (JAK)

Volume 6, No. 1 Februari Tahun 2021

Page: 154 - 169

http://ojs.uho.ac.id/index.php/iak-uho/issue/archive

e-ISSN: 2088-4656

Gambar 4.3 scatter plot diatas, terlihat secara visual nilai residual dan nilai prediksinya tidak membentuk pola tertentu (acak), sehingga dapat dikatakan bahwa model regresi dalam penelitian ini terbebas dari masalah heteroskedastisitas dan model ini layak digunakan untuk memprediksi variabel kepatuhan wajib pajak kendaraan bermotor berdasarkan masukan variabel independen kesadaran wajib pajak dan sanksi pajak.

\section{Analisis Regresi Linear Berganda}

Data hasil penelitian pada uraian deskripsi variabel, maka digunakan metode regresi linier berganda yang diolah dengan menggunakan program IBM SPSS Statistic 26, hal ini dilakukan untuk mengetahui apakah terdapat pengaruh dari variabel kepatuhan wajib pajak dan sanksi pajak terhadap kepatuhan wajib pajak kendaraan bermotor, dan dari hasil pengolahan diperoleh nilai sebagaimana yang tercantum dalam tabel sebagai berikut:

\section{Tabel 10}

\section{Hasil Analisi Regresi Linear Berganda}

\begin{tabular}{|c|c|c|c|c|c|c|c|}
\hline \multirow[b]{2}{*}{ Model } & \multicolumn{2}{|c|}{$\begin{array}{l}\text { Unstandardized } \\
\text { Coefficients }\end{array}$} & \multirow{2}{*}{$\begin{array}{l}\text { Standardized } \\
\text { Coefficients } \\
\text { Beta }\end{array}$} & \multirow[b]{2}{*}{$\mathrm{t}$} & \multirow[b]{2}{*}{ Sig. } & \multicolumn{2}{|c|}{ Collinearity Statistics } \\
\hline & $\mathrm{B}$ & Std. Error & & & & Tolerance & VIF \\
\hline (Constant) & .215 & .252 & & .852 & .397 & & \\
\hline $\mathrm{X} 1$ & .341 & .096 & .294 & 3.557 & .001 & .417 & 2.396 \\
\hline $\mathrm{X} 2$ & .612 & .081 & .625 & 7.575 & .000 & .417 & 2.396 \\
\hline
\end{tabular}

Sumber: Data Primer diolah tahun 2020

Berdasarkan Tabel 10 diatas maka dapat diperoleh persamaan Sebagai Berikut:

$$
\mathrm{Y}=0,215+0,341+0,612+\mathrm{e}
$$

1. Konstanta dengan nilai 0,215 memiliki arti bahwa apabila variabel independen kesadaran wajib pajak dan sanksi pajak sama dengan nol, maka variabel dependen kepatuhan wajib pajak kendaraan bermotor akan meningkat sebesar 0,215.

2. Koefisien X1 sebesar 0,341 memiliki arti bahwa apabila variabel kesadaran wajib pajak meningkat sebesar 1 dan variabel sanksi pajak dianggap konstan, maka kepatuhan wajib pajak kendaraan bermotor akan meningkat sebesar 0,341.

3. Koefisien X2 sebesar 0,612 memiliki arti bahwa apabila variabel sanksi pajak meningkat sebesar 1 dan variabel kesadaran wajib pajak dianggap konstan, maka kepatuhan wajib pajak kendaraan bermotor akan meningkat sebesar 0,612.

\section{Uji Hipotesis}

Pengujian hipotesis dapat dilakukan dengan membandingkan t-hitung dengan ttabel dan nilai t-sig dengan $\alpha: 0,05$. Apabila t-hitung $>\mathrm{t}$-tabel atau $\mathrm{t}$-sig $<$ dari $\alpha: 0,05$, maka diterima $\mathrm{H} 1$ atau tolak H0. Sebaliknya, apabila t-hitung $<\mathrm{t}$ tabel atau $\mathrm{t}$-sig $>$ dari $\alpha$ : 0,05 maka tolak $\mathrm{H} 1$ atau terima $\mathrm{H} 0$. 
Tabel 11

Ringkasan Uji t, Uji f dan Koefisien Determinasi

\begin{tabular}{|l|l|l|l|l|l|l|l|}
\hline \multicolumn{2}{|l|}{ Persamaan } \\
\cline { 1 - 5 } Variabel & $\mathbf{t}_{\text {hitung }}$ & $\mathbf{t}_{\text {tabel }}$ & Sig. & $\mathbf{F}_{\text {hitung }}$ & $\mathbf{F}_{\text {tabel }}$ & Sig. & R. Square \\
\hline $\mathrm{X} 1$ & 3.557 & 1,66235 & 0,001 & 133.151 & 2,712 & 0,000 & 0,758 \\
\hline $\mathrm{X} 2$ & 7.575 & 1,66235 & 0,000 & & & & \\
\hline
\end{tabular}

Sumber: Data Primer diolah tahun 2020

Tabel 11 menunjukkan bahwa t-hitung untuk variabel kesadaran wajib pajak sebesar $3.557>$ dari t-tabel yaitu sebesar 1,66235 atau tingkat signifikansi sebesar $0,001<$ dari $\alpha=$ 0,05, maka dari hasil pengujian tersebut dapat disimpulkan bahwa $\mathrm{H} 1$ diterima dan $\mathrm{H} 0$ ditolak. Hal ini menunjukkan bahwa kesadaran wajib pajak secara parsial berpengaruh terhadap kepatuhan wajib pajak kendaraan bermotor di Kota Kendari.

Tabel 11 menunjukkan bahwa t-hitung untuk variabel sanksi pajak sebesar 7.575> dari t-tabel yaitu sebesar 1,66235 atau tingkat signifikansi sebesar $0,000<$ dari $\alpha=0,05$, maka dari hasil pengujian tersebut dapat disimpulkan bahwa $\mathrm{H} 2$ diterima dan $\mathrm{H} 0$ ditolak. Hal ini menunjukkan bahwa sanksi pajak secara parsial berpengaruh terhadap kepatuhan wajib pajak kendaraan bermotor di Kota Kendari.

Tabel 11 menunjukkan bahwa tingkat signifikan $\mathrm{F}$ memiliki nilai sig. $=0,000$ lebih kecil dari nilai $\alpha=0,05$ atau $\mathrm{F}$ hitung $=133.151>\mathrm{F}$ tabel $=2,712$. Maka dari hasil pengujan tersebut dapat disimpulkan bahwa $\mathrm{H} 3$ diterima dan $\mathrm{H} 0$ ditolak. Hal ini menunjukkan kesadaran wajib pajak dan sanksi pajak secara bersama-sama berpengaruh terhadap kepatuhan wajib pajak kendaraan bermotor di Kota Kendari.

Koefisien determinasi dimaksudkan untuk mengetahui besarnya kontribusi Kesadaran wajib pajak dan sanksi pajak terhadap kepatuhan wajib pajak kendaraan bermotor, dengan melihat nilai koefisien determinasinya (r2). Pada tabel 4,16 diketahui besarnya $\mathrm{r} 2(\mathrm{R}-$ Square $)=0,758$, menunjukkan bahwa besarnya pengaruh langsung variabel kesadaran wajjib pajak (X1) dan sanksi pajak (X2) terhadap kepatuhan wajib pajak kendaraan bermotor (Y) adalah sebesar $75,8 \%$. Hal ini berarti bahwa ada variabel epsilon ( $)$ sebesar 24,2\% yang mempengaruh variabel Y namun tidak diukur dalam penelitian ini.

\section{Pembahasan}

\section{Pengaruh Kesadaran Wajib pajak Terhadap Kepatuhan Wajib Pajak Kendaraan Bermotor di Kota Kendari}

Hasil pengujian ini menunjukkan adanya pengaruh positif dan signifikan terhadap kepatuhan wajib pajak kendaraan bermotor di Kota Kendari, dapat diketahui bahwa responden cenderung menjawab setuju untuk pernyataan-pernyataan yang diajukan yang berkaitan dengan variabel kesadaran wajib pajak. Hal ini menunjukkan bahwa sebagian responden memiliki kesadaran pajak yang baik atau setuju untuk patuh membayar pajak dan hasil tersebut menunjukkan semakin tinggi kesadaran wajib pajak, maka semakin tinggi tingkat kepatuhan wajib pajak kendaraan bermotor di Kota kendari dan dapat meningkatkan jumlah penerimaan pajak di Kantor Samsat Kota Kendari.

Variabel ini terdiri dari 3 indikator yaitu Kesadaran adanya hak dan kewajiban wajib pajak, Kepercayaan masyarakat dalam membayar pajak untuk pembiayaan negara dan daerah, dan Dorongan diri sendiri untuk membayar pajak secara suka rela. Berdasarkan hasil uji analisis faktor, indikator kepercayaan masyarakat dalam membayar pajak untuk pembiayaan negara dan daerah memiliki pengaruh yang lebih tinggi di bandingkan dengan indikator yang lain. Hal ini mencerminkan bahwa kesadaran wajib pajak didasarkan atas kepercayaan masyarakat dalam membayar pajak untuk pembiayaan negara dan daerah.

Namun pada faktanya berdasarkan jumlah wajib pajak kendaraan bermotor yang menunggak dari tahun 2015 - 2019 berdasarkan data yang diperoleh dari kantor samsat 
Kota Kendari menunjukkan bahwa angka wajib pajak yang menunggak tiap tahun selalu meningkat dan berdasarkan karakteristik responden yang diperoleh dari kuesioner, menunjukkan bahwa 44\% responden masih memiliki tunggakan pajak, nilai ini menunjukkan bahwa masih cukup banyak wajib pajak yang belum sadar dan patuh dalam membayar pajaknya, tetapi berdasarkan jawaban responden dalam menjawab penyataan pada variabel kesadaran wajib pajak pada kuesioner, responden memiliki pendapat bahwa wajib pajak memiliki kesadaran dan patuh dalam membayar pajaknya.

Berdasarkan hasil uji hipotesis menggunakan analisi regresi linear berganda, hasil penelitian ini mendukung hipotesis pertama yakni kesadaran wajib pajak berpengaruh positif dan signifikan terhadap kepatuhan wajib pajak kendaraan bermotor di Kota Kendari, hal ini berdasarkan persepsi jawaban dari responden mengenai kesadaran wajib pajak. Hal tersebut didukung oleh penelitian terdahulu bahwa Kesadaran Wajib Pajak berpengaruh positif dan signifikan terhadap Kepatuhan Wajib Pajak Kendaraan Bermotor (Anis Syamsu Rizal, 2019).

Timbulnya kesadaran wajib pajak untuk membayar pajaknya disebabkan adanya kesadaran dari dalam diri wajib pajak tersebut bahwa membayar pajak adalah suatu kewajiban bagi warga negara.

\section{Pengaruh Sanksi Pajak Terhadap Kepatuhan Wajib Pajak Kendaraan Bermotor di Kota Kendari}

Hasil penelitian menunjukkan bahwa sanksi pajak berpengaruh positif dan signifikan terhadap kepatuhan wajib pajak kendaraan bermotor di Kota Kendari, dapat diketahui bahwa responden cenderung menjawab setuju untuk pernyataan-pernyataan yang diajukan yang berkaitan dengan variabel sanksi pajak. Hal ini menunjukkan bahwa sanksi pajak diperlukan untuk menghukum setiap wajib pajak yang tidak patuh dalam memenuhi kewajiban perpajakannya. Sanksi pajak yang dimaksud antara lain seperti adanya sanksi admnistrasi berupa denda bagi wajib pajak bila terlambat membayar pajak kendaraannya. Pelaksanaan sanksi pajak secara tegas akan semakin merugikan wajib pajak sehingga wajib pajak akan lebih memilih untuk patuh melaksanakan kewajiban perpajakannya. Semakin tegas sanksi pajak yang akan diberikan,maka semakin meningkat kepatuhan wajib pajak.

Variabel ini terdiri dari 3 indikator yaitu keterlambatan membayar pajak harus dikenenakan sanksi, tingkat penerapan sanksi pajak, sanksi digunakan untuk meningkatkan kepatuhan wajib pajak. Berdasarkan hasil uji analisis faktor, indikator tingkat penerapan sanksi pajak memiliki pengaruh yang lebih tinggi di bandingkan dengan indikator yang lain. Hal ini mencerminkan bahwa sanksi pajak didasarkan atas tingkat penerapan sanksi pajak.

Namun berdasarkan data yang diperoleh, pada tahun 2015 - 2019 jumlah wajib pajak yang menunggak selalu meningkat, dan berdasarkan karakteristik responden yang diperoleh dari kuesioner, sekitar $82 \%$ dari jumlah responden yang menunggak memiliki tunggakan pajak dibawah satu tahun, dan sekitar $87 \%$ memiliki denda dibawah Rp. 500.000. Hal ini menunjukan bahwa masih banyaknya wajib pajak yang melakukan pelanggaran pajak apabila sanksi pajak yang diperoleh rendah dan masih kurang memahami mengenai sanksi pajak. Tetapi berdasarkan jawaban responden dalam menjawab pernyataan pada variabel sanksi pajak dalam kuesioner, responden berpendapat wajib pajak kendaraan bermotor di Kota Kendari memiliki pemahaman yang baik dan setuju mengenai sanksi pajak.

Banyaknya wajib pajak yang melakukan penunggakan dikarenakan sistem pemungutan pajak yang masih kurang efektif. Berdasarkan hasil wawancara peneliti kepada salah satu pejabat di kantor samsat Kota Kendari, apabila seorang wajib pajak melakukan penunggakan pajak, pihak kantor samsat Kota Kendari tidak mengirimkan surat teguran ataupun teguran langsung kepada wajib pajak yang menunggak. Surat penagihan juga tidak 
diberikan dari kantor samsat Kota Kendari sebagai pengingat bagi wajib pajak untuk membayar pajaknya sebelum jatuh tempo. Jika dibandingkan dengan sistem penagihan pada kantor samsat Kota Jakarta, mereka telah melakukan sistem penagihan tersebut dan selalu memberikan pemberitahuan agar memenuhi kewajiban membayar pajak kepada penunggak pajak setiap 14 hari sebelum jatuh tempo (Kompas.com, 2019). Wajib pajak kendaraan bermotor di Kota Kendari yang melakukan penunggakan hanya akan diberikan denda sesuai dengan keterlambatan membayar pajaknya ketika datang ke kantor samsat untuk membayar pajaknya, hal ini tidak memberikan efek jera bagi wajib pajak untuk melakukan penunggakan pajak.

Berdasarkan hasil uji hipotesis menggunakan analisi regresi linear berganda, hasil penelitian ini mendukung hipotesis kedua yakni sanksi pajak berpengaruh positif dan signifikan terhadap kepatuhan wajib pajak kendaraan bermotor di Kota Kendari, hal ini berdasarkan persepsi jawaban responden mengenai sanksi pajak. Penelitian ini didukung oleh penelitian terdahulu bahwa sanksi pajak memiliki pengaruh yang signifikan terhadap kepatuhan wajib pajak kendaraan bermotor (Dian Angriani dan Siti Khairani, 2018).

Pada dasarnya timbulnya kepatuhan wajib pajak dalam membayar pajaknya biasa disebabkan karena wajib pajak lebih takut dengan sanksi yang diberikan apabila tidak membayar pajak atau melanggar undang-undang perpajakan.

\section{Pengaruh Kesadaran Wajib Pajak dan Sanksi Pajak Terhadap Kepatuhan Wajib Pajak Kendaraan Bermotor di Kota Kendari}

Hasil pengujian hipotesis memperlihatkan bahwa X1, X2 dan memiliki nilai sig. = 0,000 lebih kecil dari nilai $\alpha=0,05$ atau F hitung $\mathrm{F}$ hitung $=133.151$ lebih besar dari $\mathrm{F}$ tabel $=2,712$ dan nilai koefisien determinasi sebesar 0,758 atau 75,8\% yang artinya kesadaran wajib pajak dan sanksi pajak memiliki pengaruh yang signifikan terhadap kepatuhan wajib pajak kendaraan bermotor.

Hasil tersebut menerima hipotesis ketiga (H3) dalam penelitian ini yakni kesadaran wajib pajak dan sanksi pajak berpengaruh terhadap kepatuhan wajib pajak kendaraan bermotor di Kota Kendari. Hal ini menunjukkan kesadaran wajib pajak dan sanksi pajak dapat dipertahankan bahkan ditingkatkan maka akan meningkatkan kepatuhan wajib pajak kendaraan bermotor secara signifikan.

Kesadaran wajib pajak dan sanksi pajak secara simultan berpengaruh terhadap kepatuhan wajib pajak kendaraan bermotor. Penelitian ini didukung oleh penelitian terdahulu bahwa kesadaran wajib pajak dan sanksi pajak berpengaruh secara signifikan terhadap kepatuhan wajib pajak kendaraan bermotor (Muslikhatul Ummah, 2015).

Kesadaran wajib pajak didukung dengan adanya sanksi pajak yang ditetapkan dalam undang-undang harus memberikan sanksi yang tegas kepada wajib pajak yang terlambat membayar pajaknya sehingga wajib pajak patuh dalam membayar pajaknya. Semakin tinggi sanksi yang diberikan, maka semakin patuh wajib pajak dalam membayar pajaknya.

\section{Kesimpulan}

\section{KESIMPULAN DAN SARAN}

1. Kesadaran wajib pajak secara parsial berpengaruh terhadap kepatuhan wajib pajak kendaraan bermotor. Hal ini menunjukkan bahwa semakin tinggi kesadaran wajib pajak, maka semakin patuh wajib pajak dalam membayar pajak. Namun masih terdapat masalah dikarenakan pada faktanya masih banyak wajib pajak yang tidak patuh dalam membayar pajaknya walaupun mereka berpendapat memiliki kesadaran yang baik dan patuh dalam membayar pajak.

2. Sanksi pajak secara parsial berpengaruh terhadap kepatuhan wajib pajak kendaraan bermotor. Hal ini menunjukkan bahwa semakin tinggi sanksi pajak yang diberikan maka 
semakin patuh wajib pajak dalam membayar pajak. Namun pada faktanya, karena jumlah denda yang masih dalam kategori rendah, sehingga masih banyak wajib pajak yang melakukan penunggakan pajak.

3. Kesadaran wajib pajak dan sanksi pajak secara simultan berpengaruh terhadap kepatuhan wajib pajak kendaraan bermotor. Hal ini menunjukkan bahwa semakin tinggi kesadaraan wajib pajak dan semakin tegas sanksi pajak yang diberikan kepada wajib pajak maka akan semakin patuh wajib pajak dalam membayar pajaknya.

\section{Implikasi}

Kesadaran wajib pajak dan sanksi pajak terbukti memberikan pengaruh terhadap kepatuhan wajib pajak kendaraan bermotor di Kota Kendari. Oleh karena itu kesadaran dan sanksi pajak harus terus ditingkatkan untuk mendorong wajib pajak kendaraan bermotor di Kota Kendari agar patuh akan kewajiban perpajakannya.

\section{Keterbatasan}

Penelitian ini memiliki beberapa keterbatasan yang mungkin dapat melemahkan hasilnya. Beberapa keterbatasan dalam penelitian ini antara lain sebagai berikut:

1. Penelitian ini hanya mengukur dua variabel independen saja, kemungkinan masih banyak variabel lain yang dapat mempengaruhi kepatuhan wajib pajak kendaraan bermotor.

2. Penelitian ini hanya terbatas pada wajib pajak kendaraan bermotor di Kota Kendari saja, sehingga belum tergeneralisasi secara baik.

\section{Rekomendasi}

Beberapa saran dan rekomendasi yang diajukan penulis berdasarkan kesimpulan dan hasil penelitian ini adalah sebagai berikut :

1. Untuk meningkatkan kepatuhan wajib pajak, pihak Kantor Samsat Kota Kendari dapat mengadakan

a. Sosialisasi kepada masyarakat secara rutin berupa seminar, sosialisasi perpajakan yang dapat menambah pengetahuan dan pemahaman diri wajib pajak terhadap peraturan perpajakan dan dapat membantu meningkatkan sikap sadar membayar pajak agar masyarakat mau untuk membayar pajak.

b. Meningkatkan sistem penagihan kepada wajib pajak yang melakukan penunggakan agar wajib pajak patuh membayar pajaknya.

c. Lebih meningkatkan regulasi mengenai sanksi pajak yang memberikan efek jera bagi wajib pajak agar tidak melakukan penunggakan pajak.

Karena walaupun hasil dalam penelitian ini memiliki pengaruh positif dalam meningkatkan kepatuhan wajib pajak kendaraan bermotor di Kota Kendari, namun pada faktanya masih banyak wajib pajak yang melakukan penunggakan pajak.

2. Bagi peneliti selanjutnya yang bermaksud melakukan penelitian yang sama, dapat mempertahankan dan meningkatkan indikator yang memiliki pengaruh lebih tinggi dalam suatu variabel, dan meningkatkan indikator-indikator yang lainnya. Dan sebaiknya menambah jumlah variabel yang mempengaruhi kepatuhan wajib pajak kendaraan bermotor sehingga dapat diketahui faktor apa saja yang dapat mempengaruhi kepatuhan wajib pajak kendaraan bermotor, karna pada faktanya menunjukkan bahwa walaupun wajib pajak berpendapat wajib pajak kendaraan bermotor di Kota Kendari memiliki kesadaran dan memahami sanksi pajak, namun kenyataannya masih banyak wajib pajak yang melakukan penunggakan pajak. Dan memperluas area penelitian serta menambah jumlah sampel agar dapat lebih di generalisasi. 


\section{DAFTAR PUSTAKA}

Angraini, Dian dan Siti Khairani. 2018. Pengaruh kesadaran wajib pajak dan sanksi pajak terhadap kepatuhan membayar pajak kendaraan bermotor (studi kasus pada wpop kendaraan bermotor di kota palembang). Jurnal Jurusan Akuntansi STIE Multi Data Palembang.

Danang, Sunyoto. 2013. Metodologi Penelitian Akuntansi. Bandung: PT Refika Aditama Anggota Ikapi.

Ghozali, Imam. 2018. Aplikasi Analisis Multivariate dengan Program IBM SPSS 25. Semarang: Badan Penerbit Universitas Diponegoro.

Mardiasmo. 2018. Perpajakan. Edisi Terbaru. Yogyakarta: CV Andi Offset .

Mutia, Sri Putri Tita. (2014). "Pengaruh Sanksi Perpajakan, Kesadaran Perpajakan, Pelayanan Fiskus, Dan Tingkat Pemahaman Terhadap Kepatuhan Wajib Pajak Orang Pribadi (Studi Empiris Pada Wajib Pajak Orang Pribadi Yang Terdaftar Di KPP Pratama Padang)". Artikel Ilmiah. Program Studi Akuntansi Fakultas Ekonomi Universitas Negeri Padang.

Nazaruddin dan Basuki, 2016, Analisis Statistik Dengan SPSS. Yoyakarta: Danisa Media.

Rahayu, Siti Kurnia, 2010. Perpajakan Indonesia: Konsep dan Aspek Formal. Yogyakarta: Graha Ilmu.

Resmi, Siti. (2018). Perpajakan, Teori dan Kasus. Jakarta: Salemba Empat

Rizal, Anis Syamsu. 2019. Pengaruh pengetahuan wajib pajak, kesadaran wajib pajak, sanksi pajak kendaraan bermotor dan sistem samsat drive thru terhadap kepatuhan wajib pajak kendaraan bermotor. Jurnal Prodi S 1 Akuntansi Universitas Pamulang.

Solimun, Adji A. R. Fernandes, Nurjannah. 2017. Pemodelan Persamaan Struktural (SEM) Pendekatan WarpPLS. Malang: UB Press.

Suryarini, Trisni dan Tarsis Tarmudji. 2012. Pajak di Indonesia. Graha Ilmu. Yogyakarta.

Ummah, Muslikhatul. 2015. Pengaruh kesadaran wajib pajak, sanksi pajak, pengetahuan perpajakan dan pelayanan fiskus terhadap kepatuhan wajib pajak kendaraan bermotor di kabupaten semarang. Jurnal Fakultas Ekonomi Universitas Dian Nuswantoro, Semarang, Indonesia.

Wardani, Dewi Kusuma; dan Rumiyatun. 2017. "Pengaruh Pengetahuan Wajib Pajak, Kesadaran Wajib Pajak, Sanksi Pajak Kendaraan Bermotor, Dan Sistem SAMSAT Drive Thru Terhadap Kepatuhan Wajib Pajak Kendaraan Bermotor" (Studi kasus WP PKB roda empat di kantor SAMSAT Drive Thru Bantul). Jurnal Akuntansi, Vol. 5, No.2, Juni 2017 